\title{
Examining Patterns of Food Exchange and Dependency at
} Moose Fort, 1783-1785

Daniel Ruten*

\begin{abstract}
Many historians studying the fur trade have argued or assumed that Indigenous peoples swiftly became dependent on the fur trading posts in North America for their survival. In order to gain insight into native-newcomer relations but also particularly to address the question of dependency, this paper examines patterns of food exchange between Hudson's Bay Company men employed at Moose Fort and the James Bay Cree homeguard that lived near the Fort from October 1783 to September 1785. It finds that the flow of foodstuffs from Indigenous peoples to Moose Fort greatly outweighed the flow of food from the Fort to Indigenous peoples. Furthermore, this paper will argue that the traders of Moose Fort were consistently reliant upon these provisions supplied by Indigenous hunters, trappers, and fishers, as periods when most Indigenous providers were absent from the area resulted in conditions of food crises at the Fort. Thus, the relations of food exchange at Moose Fort provided mutual benefits to both parties, but it was ultimately the Fort itself that was more dependent upon this relationship. Overall, this evidence calls for more nuanced and less one-sided theoretical models of dependency in the history of the fur trade.
\end{abstract}

Keywords: fur trade, history, 18th century, North America, native-newcomer relations, Indigenous

The James Bay Cree story "Chakaapaash Encounters Whitemen" describes an original encounter between Native and Newcomer. In it, the Cree hero Chakaapaash encounters a ship floating off the coast of his homeland one day. Out of curiosity, he boards it, and the people on the ship give him "Whiteman's food", a kind of food he had never tasted before. The whitemen on the ship tell Chakaapaash to give them some food in return. In response, Chakaapaash brings them a single leg of a red squirrel. But as he places the leg down on the ship, its weight is revealed to be so great that it rocks the ship dramatically, and it ends up feeding all of the whitemen. ${ }^{1}$

${ }^{1}$ Colin Scott, "Encountering the Whiteman in James Bay Cree Narrative History and Mythology," Aboriginal History 19 no.1 (1995), 24 ; Hans M. Carlson, Home is the Hunter: The James Bay Cree and Their Land (Vancouver: UBC Press, 2008), 63. This narrative was related by Geordie Georgekish, a Wemindji Cree elder, in 1979.

\footnotetext{
*Department of History, College of Arts and Science, University of Saskatchewan, Saskatoon, SK, Canada
}

Correspondence: dar154@mail.usask.ca 
It is significant that this James Bay Cree legend frames the original formation of Native-Newcomer relations as being based around the exchange of food. Food exchange was viewed by the Cree as the most sacred and fundamental means by which a relationship of reciprocity could be established between two parties. ${ }^{2}$ In "Chakaapaash Encounters Whitemen," the whitemen make the mistake of straightforwardly asking for food in return, which is a breach of Cree etiquette, as typically only one who was already in a well-established partnership with another would ask for something so directly. In response, Chakaapaash brings them a single leg of a squirrel, an offer that appears so ridiculously small that it seems spiteful, but in actuality is revealed to be a more-than-ample gift that tremendously outweighs the generosity of the whitemen. ${ }^{3}$

The James Bay Cree's emphasis on food exchange and reciprocity can also be seen in their historical relations with Hudson's Bay Company fur traders at the various trading posts in the James Bay region. This paper will focus on these relationships at Moose Fort from October 1783 to September 1785, relying mainly on the surviving Fort journals and correspondence books from this period. The first fur trading post in the area, now known as Moose Factory, was established by the Hudson's Bay Company in 1673. It was built near the mouth of the Moose River, where the river drains into the southwestern tip of James Bay (which lies immediately south of Hudson Bay). The post slowly grew in importance until the French captured it in 1686. It was returned to British control in 1713, but was not used thereafter until the construction of a new trading post at Moose in 1730. This reconstruction was at least partially in answer to the local Indigenous people's demands that a post be established closer to their hunting grounds than Fort Albany, which was located about one hundred miles north of Moose. The ever-present threat of French Canadian competition was also a significant factor, as the Fort's southern proximity to Canada left it constantly exposed to French competition and rivalry. ${ }^{4}$

Soon after the new post's establishment, communities of Indigenous hunters and their families

2 Scott, "Encountering the Whiteman in James Bay Cree Narrative History and Mythology," 25. As Scott explains, this particular Cree mythological or legendary narrative (aatiyuuhkaan) is contrasted from its corresponding historical narratives (tipaachimuun), which describe the reciprocal relationship with Whitemen as being established around the exchange of secular trade items.

3 Scott, "Encountering the Whiteman in James Bay Cree Narrative History and Mythology," 24.

${ }^{4}$ Carol M. Judd, "Mixed Bloods of Moose Factory, 1730 -1981: A SocioEconomic Study," American Indian Culture and Research Journal 6, no. 2 (1982), 66; G.P. de T. Glazebrook, Introduction to Moose Fort Journals 1783-85, ed. E.E. Rich (London: The Hudson's Bay Record Society, 1954), xxiii. formed a relationship of food exchange with the Fort based around the traditional seasonal fall and spring goose hunt. They stayed at the post, expecting to be fed, for about a month during each hunt, and then brought excess geese to supply the Fort. In exchange, they were given gunpowder, brandy, and other European trade items. This exchange quickly turned into a biannual tradition, and after a time, these Indigenous hunters started to also leave their elderly and sick under the Fort's care while they went out to fish in the summer, or to hunt and trap in the winter. In times of deprivation, they also expected the Fort to provide them with food until the goose season came around again. Similar arrangements had arisen among many other Hudson's Bay Company's posts. These people became referred to as "homeguard" or "home Indians" and were distinguished from the "uplanders" or "inland Indians" who lived further away from the Fort and did not provide it with food. ${ }^{5}$ These traditions and nomenclatures continued unabated into the late eighteenth century.

Historians have long argued that Indigenous people became dependent on and subject to the Forts in the fur trade for their survival. Historian Donald Bibeau has outlined this belief in Indigenous dependency as one of the fundamental assumptions contained in most fur trade scholarship. ${ }^{6}$ From early on, this notion of dependency was linked to assumptions of Indigenous cultural inferiority. For instance, historian J. M. S. Careless argued in 1953 that "the weaker, more primitive Indian tribal life simply collapsed and fell apart as it met a more advanced civilization" before going on to say, "Like other Indian tribes in contact with white men, the Iroquois had become dependent on European goods for their very survival. ${ }^{\prime \prime 7} \mathrm{E}$. E. Rich, in his 1958 history of the Hudson's Bay Company, went so far as to suggest that Indigenous people started to become dependent on European provisions for their survival "from the start" of the Company in the 1670s, highlighting the supposed "danger threatening the trader and the Indian

${ }^{5}$ Judd, "Mixed Bloods of Moose Factory," 66.

${ }^{6}$ Donald Bibeau, "Fur Trade Literature from a Tribal Point of View: A Critique," in Rethinking the Fur Trade: Cultures of Exchange in an Atlantic World, ed. Susan Sleeper-Smith (Lincoln: University of Nebraska Press, 2009): 69-71.

7 J.M.S. Careless, Canada: A Story of Challenge (Toronto: Macmillan Company of Canada Ltd., 1970), 22, 44; Toby Morantz, "Old Texts, Old Questions: Another Look at the Issue of Continuity and the Early Fur Trade Period," The Canadian Historical Review 73, no. 2 (June 1992), 167. The assumption of Indigenous cultural inferiority was indeed a fundamental aspect of early literature on the fur trade; in Harold Innis' seminal 1930 history of the fur trade, for example, he contended that "the fur trade was the means by which the demand of the peoples of a more limited cultural development was met." Harold Innis, The Fur Trade in Canada: An Introduction to Canadian Economic History (Toronto: Toronto University Press, 1970), 389. 
alike if shipping failed and they became completely dependent on the resources of the country. ${ }^{\prime 8}$

These assumptions of dependency continued into the 1970 s and 1980s, but increasingly took on new contours. In a Marxist analysis, historian and anthropologist Harold Hickerson portrayed Indigenous hunters in the fur trade as a sort of "forest proletariat" who were subject to the authority of the post managers, overall "constituted in every sense an oppressed class," and thus implicitly lacked individual autonomy. ${ }^{9}$ For Hickerson, the provision of food by the Forts formed a part of this relationship of dependency; he argued that "the introduction of food by the trader increased the Indians' reliance on him. ${ }^{\prime 10}$ Meanwhile, the highly influential fur trade historian Richard White largely based his model of Indigenous dependency around the 'core-periphery' world systems economic theory that had come to prominence in the 1970s. In his 1983 book The Roots of Dependency, White argued that by entering into the markets of Europeans through the fur trade, the Mississippi Choctaws were almost inevitably drawn into a state of dependency on the market for their survival through the eighteenth century, and by the end of the century they effectively lacked any other economic choices. ${ }^{11}$ For the most part, these models of dependency avoided previous presumptions of Indigenous cultural inferiority, but they also tended to portray Indigenous actors in the fur trade as an overly passive, almost "universal kind of victim." ${ }^{12}$ Arguments or assumptions of Indigenous dependency were also applied to the people of the Western James Bay region; historian Charles A. Bishop has argued that "the willingness of traders to tide destitute

8 Morantz, "Old Texts, Old Questions: Another Look at the Issue of Continuity and the Early Fur Trade Period," 169. Here, Rich posits "the marked tendency for the Indian to become dependent on the trader" to be "one of the permanent features of the Company's trade." E.E. Rich, The History of the Hudson's Bay Company, 16701870, vol. 1 (London: Hudson's Bay Record Society, 1958), 71.

9 Harold Hickerson, "Fur Trade Colonialism and the North American Indian," The Journal of Ethnic Studies 1, no. 2 (Summer 1973), 15, 39; Toby Morantz, The White Man's Gonna Getcha: The Colonial Challenge to the Crees in Quebec (Montreal: McGill-Queen's University Press, 2002), 21.

10 Hickerson, "Fur Trade Colonialism and the North American Indian," 29.

${ }^{11}$ Richard White, The Roots of Dependency: Subsistence, Environment and Social Change Among the Choctaws, Pawnees, and Navajos (Lincoln: University of Nebraska Press, 1988), 146; Stephen P. Van Hoek, "Untangling the Roots of Dependency: Choctaw Economics, 17001860," American Indian Quarterly 23, No. 3/4 (Summer-Autumn, 1999), 114-115, 121-122. Van Hoek rejects White's narrative of Choctaw dependency, instead contending that the Choctaws' responses to economic and political changes through the 18th century are best characterized by a model of adaptability.

12 Morantz, The White Man's Gonna Getcha, 24; Van Hoek, "Untangling the Roots of Dependency," 114.
Indians over... created a recurrent dependence [of the Western James Bay Cree] on post assistance. ${ }^{\prime \prime 13}$ Carol M. Judd similarly describes the Indigenous 'homeguard' of Moose Fort as having "long since given up their independence to attach themselves... to the security of the trading post" by the mid-18th century. ${ }^{14}$

However, as this paper will argue, the Moose Fort journals and correspondence books from 1783 to 1785 reveal a markedly different relationship between the traders and the Indigenous people living near the Fort, a relationship that calls for more nuanced theoretical models. From the patterns of food exchange recorded in these journals, it becomes clear that the Hudson's Bay Company men of Moose Fort were continually dependent upon Indigenous hunters, fishers, and trappers to provide the means for their subsistence during the late eighteenth century. These "homeguard" Indigenous providers expected to receive European goods in exchange for the provisions they brought to the fort, and they also expected to be given provisions by the fort when they needed it, as such expectations were in accordance with Cree values of reciprocity. The Fort complied and provided small amounts of food to both the homeguard and to visitors from inland regions claiming to be in need; this was a pragmatic means for the traders to maintain the economic relationship of food exchange which they were dependent upon to provision the Fort. Notably, the flow of foodstuffs from Indigenous providers to the Fort vastly outweighed the flow of food from the Fort to Indigenous peoples, suggesting how vital the Indigenous providers were to the traders' livelihood. Furthermore, far from being utterly dependent on the fort for their own subsistence, as contended by historians such as Rich, the Moose Fort homeguard demonstrated that the opposite was true since their occasional absences tended to foment shortages and food crises at the Fort. Thus, the forms of food exchange at Moose Fort provided mutual benefits to both parties, but ultimately, it was the traders who were more dependent upon this relationship. Overall, these findings emphasize that any model or discussion of Indigenous dependency in the fur trade remains incomplete without consideration of

${ }^{13}$ Charles A. Bishop, "The First Century: Adaptive Changes Among the Western James Bay Cree between the Early Seventeenth and Early Eighteenth Centuries," in The Subarctic Fur Trade: Native Social and Economic Adaptations, ed. Shepard Krech (Vancouver: University of British Columbia Press, 1984), 45-46.

${ }^{14}$ Carol M. Judd, "Sakie, Esquawenoe, and the Foundation of a DualNative Tradition at Moose Factory," in The Subarctic Fur Trade: Native Social and Economic Adaptations, ed. Shepard Krech (Vancouver: University of British Columbia Press, 1984), 93-94. 
the simultaneous dependency of fur traders upon Indigenous people. ${ }^{15}$

As mentioned, the relationship of food exchange between the British fur traders at Moose Fort and the local Indigenous people was reciprocal, and required that the Fort provide food to Indigenous people when needed. Thus, between October 1783 and September 1785, the Moose Fort journals refer to thirteen occasions that the Fort provided food to Indigenous people. Perhaps the most significant of these mention feeding the homeguard. On April 15, 1784, John Thomas, the Chief at Moose Fort, reported that "I have now 80 Indians (young and old) to feed daily," and his entry for the following day noted that he "Gave the Indians their accustomed feast." ${ }^{16}$ The Company likely had at least some Indigenous people staying at the Fort to provision for most of the year, but these are the only instances where they are mentioned in the journals or the correspondence books. The entry significantly coincides with the annual spring goose hunt, a time when many Indigenous people came to the coast to hunt before providing their excess food to the Fort. The Fort would then be obliged to provision these Indigenous hunters and their families while they awaited the arrival of the geese. ${ }^{17}$ Almost all of the other direct references in the journals mention individual Indian men or women coming into the Fort from elsewhere for "Victuals" (i.e., provisions), while sometimes also bringing some furs to trade. ${ }^{18}$

British fur traders provided Indigenous people with these provisions as a pragmatic means to maintain good relations with Indigenous people and to promote trade with them. This required providing food during times of hardship but included expectations for repayment. In March of 1784, for example, John Thomas mentioned in a letter to the chief of Albany that:

One of your Indians (Sussass) \& Family came in here in a starved Condition the 18th Ulto. I kept him 'till the 29th following to recruit his strength and spirits \& set him off again with as

${ }^{15}$ Daniel Francis and Toby Morantz, Partners in Furs: A History of the Fur Trade in Eastern James Bay, 1600-1870 (Montreal: McGill-Queen's University Press, 1983), 168.

16 John Thomas, A Journal of the most remarkable Transactions and Occurrences at Moose Fort from 2d Octor. 1783 to 16th Septr. 1784 (1784), in E. E. Rich, ed., Moose Fort Journals 1783-85 (London: The Hudson's Bay Record Society, 1954), 41.

17 Judd, "Mixed Bloods of Moose Factory," 66; Bishop, "The First Century," 37; Francis and Morantz, Partners in Furs, 93.

18 See for example John Thomas, A Journal of the most remarkable Transactions and Occurrences at Moose Fort from 17th September 1784 to 22d September 1785 (1785), in E. E. Rich, ed., Moose Fort Journals 1783-85 (London: The Hudson's Bay Record Society, 1954), 84, 88, 92, 100, and 101. much Victuals as I hope will enable him to pay his Debt of which he had not then a single Skin of any kind. ${ }^{19}$

Thomas emphasizes that he has given provisions to this 'starved Indian' so that he will better be able to go out and procure more furs to trade to the Fort. The Indigenous people, meanwhile, would have most likely considered this provisioning in times of scarcity to be an expected part of their reciprocal relationship of food exchange with the Forts' traders. ${ }^{20}$ Maintaining these good relations was also important for the traders in the context of the Hudson's Bay Company's competition with the North West Company at the time; the Indigenous peoples of James Bay could always go to the HBC's rivals if they at any time were unhappy with how they were being treated, and the Company's managers did not take this as an idle threat. ${ }^{21}$

Above all, though, the Company men of Moose Fort worked to maintain this reciprocal relationship of food exchange because they were continually dependent upon the provisions brought by Indigenous people for their own subsistence. From 1783 to 1785 , the Moose Fort Journals noted 149 instances of the Fort receiving food from Indigenous people, including geese, fish (such as 'Methy' i.e., Burbot, Sturgeon, and large Jack), rabbits, ducks, and plover. ${ }^{22}$ Fort records inconsistently recorded the quantities received, but they suggest the existence of a substantial food exchange network. For example, the Fort regularly received thirty to 150 pounds of food, often fish or rabbits, in a single day during the spring or the summer months. ${ }^{23}$ Additionally, there are numerous scattered entries that report receipts of rabbits in fairly small quantities from old women or men. ${ }^{24}$ These were presumably elderly Indigenous members of the Fort's homeguard who were engaged in trapping.

Moose Fort depended on the flow of these socalled 'country provisions' as European provisions were often lacking and therefore reserved exclusively for service to inland settlements (except in times of food crisis). In one letter to Edward Jarvis, the Chief of Albany Fort, Moose Fort Chief John Thomas mentions, "I am not so well supplied

19 John Thomas to Edward Jarvis, Moose Fort, 21 March 1784, in E. E. Rich, ed., Moose Fort Journals 1783-85 (London: The Hudson's Bay Record Society, 1954), 176.

${ }^{20}$ Francis and Morantz, Partners in Furs, 94.

${ }^{21}$ Morantz, The White Man's Gonna Getcha, 18; Judd, "Sakie, Esquawenoe, and the Foundation of a Dual-Native Tradition at Moose Factory," 90.

22 See for example Thomas, A Journal... (1784), in Moose Fort Journals $1783-85,8,38, \& 54$.

${ }^{23}$ Thomas, A Journal... (1784), in Moose Fort Journals 1783-85, 57, 58.

${ }^{24}$ See for example Thomas, A Journal... (1784), in Moose Fort Journals 1783-85, 19, 22, 23, 26, 29. 
from Europe... as you are, " before noting the importance of country provisions. ${ }^{25}$ Edward Jarvis had written to Thomas detailing his severe dearth of country provisions for the winter, lamenting, "what a cruel thing to be obliged to use the European Provisions intended for Inland Service at the Factory. ${ }^{\prime \prime 26}$ European provisions were typically reserved for the inland settlements of a Fort that depended on them; this quotation illustrates the Company's general opposition to using European provisions at the Forts themselves except in times of scarcity and food crisis. John Thomas' instructions to the Master of Brunswick House (an inland dependency of Moose Fort) in 1783 further reveal the prioritization of country provisions: "You'll Continue to Endeavor to procure as much Country Provisions as possible in order to lighten the Expence and Trouble of Supplying you with European Provisions paying the Indians for what they bring you at the usual rates..." ${ }^{27}$ It appears that even in the inland settlements that they were intended for, European provisions were generally avoided as much as possible. Thus, the provisions brought by Indigenous hunters and trappers were crucial to both the Fort and its dependencies' continued operation.

Moose Fort's reliance on Indigenous hunters was particularly pronounced during the seasonal Geese Hunts, when the Indigenous homeguard supplied the Fort with thousands of pounds of meat. The James Bay Cree had always traditionally migrated to the coast of James Bay to hunt geese in the spring, and as discussed earlier, the tradition of Indigenous hunters providing geese to Moose Fort in exchange for various European trade items had been established by the end of the first season in $1730 .{ }^{28}$ As the community of homeguard Indigenous people grew, the expectations of both the homeguard and of the Fort became more and more well established. The Moose Fort homeguard continually held the responsibility of providing the Europeans at the post with 'country provisions,' especially during the Goose Hunts, and received various trade items in return. Because members of the homeguard were limited to the coastal region while staying near the Fort, which had fewer animals to hunt (especially fur-

25 John Thomas to Edward Jarvis, Fort Moose, 17 October 1783, in E. E. Rich, ed., Moose Fort Journals 1783-85 (London: The Hudson's Bay Record Society, 1954), 151.

${ }^{26}$ Edward Jarvis to John Thomas, Fort Albany, 10 October 1783, in E. E. Rich, ed., Moose Fort Journals 1783-85 (London: The Hudson's Bay Record Society, 1954), 150.

27 John Thomas Instructions to P. Turnor, Moose Fort, 9 October 1783, in E. E. Rich, ed., Moose Fort Journals 1783-85 (London: The Hudson's Bay Record Society, 1954), 157.

${ }^{28}$ Judd, "Mixed Bloods of Moose Factory," 65-66. bearing animals), they also expected to be given European provisions in times when their own supplies were scant. ${ }^{29}$

In the period under discussion, the Goose Hunt seemed to be of utmost importance to John Thomas, the Chief at Moose Fort, as a crucial means to provision the post throughout the lengthy, arduous winter. As a result, it comes up often in both the journals and in correspondence, and the amounts of meat the Goose Hunts provided are revealed to be very substantial. In the journal entry for October $25^{\text {th }}, 1783$, Thomas reports:

The goose hunting Indians came in having left off hunting, the Geese being all gone - by a letter from Mr. Donald I find he has salted only 7 Hogsheads of Geese, which is all my store for the ensuing winter, a remarkable scarce goose season, for I have been obliged to Victual the Sloops, and Boats, with salt victuals, and frequently serve salt Geese (remains of last year) to the few people at home. ${ }^{30}$

Elsewhere in the journal, it is revealed that one Hogshead holds approximately 130 salted geese. ${ }^{31}$ Therefore, seven Hogheads would equal approximately 910 geese, which was evidently an unusually meagre take for the fall goose hunt. By contrast, on one day in October of the following year the Fort received twelve Hogsheads, about 1560 salted geese, from nearby Hannah Bay (one of the hunting sites). ${ }^{32}$ The journals also record substantial numbers of geese procured from the Spring Hunts; during May of 1784 alone, for example, the Fort received $13171 / 2$ geese in total, with the Fort receiving more than 300 geese in a single day on at least two separate occasions. ${ }^{33}$ These instances help to provide a better picture of what may have comprised a more typical haul of geese.

European traders sometimes took part in the hunt, but typically played a supporting role to the Indigenous hunters. One journal entry, for example, reports "twelve men in the marsh hunting, and serving the Indians powder and shot, \& receiving \& curing geese" ${ }^{134}$ while another states that "serving hunting Indians powder and shot prevented our performing Divine Service." ${ }^{135}$ These examples suggest that the traders' main role in the hunts was to provide the

\footnotetext{
${ }^{29}$ Morantz, The White Man's Gonna Getcha, 24; Judd, "Sakie, Esquawenoe, and the Foundation of a Dual-Native Tradition at Moose Factory," 82.

${ }^{30}$ Thomas, A Journal... (1784), in Moose Fort Journals 1783-85, 13.

${ }^{31}$ Thomas, A Journal... (1785), in Moose Fort Journals 1783-85, 79.

32 Ibid., 82.

33 Thomas, A Journal... (1784), in Moose Fort Journals 1783-85, 45-48.

${ }^{34}$ Ibid., 46.

${ }^{35}$ Ibid., 81.
} 
Indigenous hunters with supplies to facilitate the hunt. Thus, the Indigenous hunters were the primary actors in the goose hunt to provision the post, while traders' contributions appear to be secondary and are often imbued with a sense of servility to the Indigenous hunters' needs.

Also, in leaner times (particularly during the winter), the traders at Moose Fort could and did engage in hunting, trapping, or fishing, ${ }^{36}$ but their contributions were again only supplementary to the supplies received from Indigenous people. For example, the journal entry for March 51784 reports: "Recd. 20 Rabbits and 28lbs Methy from Indians and three Methy from our hooks" (emphasis added). ${ }^{37}$ The entry from January 17,1784 reports: "Recd. 70 Partridges 10 Rabbets, 2 Methy \& 12 Trout and from an old man Rabbets and Fish, from home hunters and fishermen 10 Partridges, 2 Rabbits \& 3 Methy" (emphasis added), ${ }^{38}$ and another from two days later reports receiving "2 Methy from our hooks and 20 Rabbets from 2 old women. ${ }^{\prime \prime 39}$ It seems to be mainly in the wintertime that the men of the Fort engaged in hunting to supplement the provisions of the Fort. Gardens were also likely cultivated at the Fort, ${ }^{40}$ but their yields (or even their existence) are unfortunately not mentioned in the journals nor in the extant correspondence from the period under discussion. However, other evidence suggests that from about 1777 on, local Indigenous labour started to play a significant role in the cultivation of these gardens as well (particularly in the harvesting of crops)..$^{41}$

How much food Moose Fort actually received from Indigenous people depended not only on how much food Indigenous hunters, trappers, and fishers were able to procure, but it also depended on whether or not they decided to visit or stay near the Fort to provide food in the first place. Periods when Indigenous hunters stayed away reveal the full extent of the Fort's dependence on them. In a letter to George Atkinson at the Eastmain post in March 1784, John Thomas relates that "I have so little prospect of a Spring Hunt all my Indians intending to stay away, to build Canoes that I must rely on your sending sufficient Provisions..." ${ }^{42}$ And in another letter to Atkinson in April, Thomas laments, "the poor prospect I have of a Spring Hunt (scarsely [sic] any of my Indians having come in)" before again requesting "in a most urgent manner" provisions

\footnotetext{
${ }^{36}$ Glazebrook, Introduction to Moose Fort Journals 1783-85, xxvii.

37 Thomas, A Journal... (1784), in Moose Fort Journals 1783-85, 33.

${ }^{38}$ Ibid., 26.

${ }^{39}$ Ibid.

${ }^{40}$ Glazebrook, Introduction to Moose Fort Journals 1783-85, xxviii.

${ }^{41}$ Judd, "Mixed Bloods of Moose Factory," 69.

42 John Thomas to George Atkinson, Moose Fort, 9 March 1784, in E. E. Rich, ed., Moose Fort Journals 1783-85 (London: The Hudson's Bay Record Society, 1954), 170.
}

"which... we shall stand much in need of.." ${ }^{143}$ Atkinson's reply in April apologetically explains that "I am afraid I shall not be able to supply the Sloopers with their Summer's Stock for I shall have no Indians here to hunt this spring, as they all stay Inland... [and] I cannot spare people to hunt. ${ }^{1 / 4}$

Conditions of food crisis seem to have ensued at the Fort due to the absence of Indigenous hunters, as Thomas wrote again to Albany Fort in July 1784 that "[Moose Fort] had a very poor spring Hunt indeed I fear we shall hardly make both ends meet, for it is very little the Indians bring me now, ${ }^{\prime \prime 5}$ illustrating Moose Fort's dependence on Indigenous providers to avoid food crisis both during the goose hunts and afterward. These pressures of food crisis appear to have continued into September, as on September 18, 1784 Thomas instructed one of his men to "dispatch the Indians (that accompany Mr. Donald) on their return as soon as possible so that they may assist at the Goose Hunt, which at present bears but an indifferent aspect the Indians not bringing even as much as will serve the Men" (emphasis added). ${ }^{46}$

Moose Fort also faced pressures of low food supply the following year due to a lack of provisions from Indigenous providers; a letter Thomas wrote to Albany in July 1785 explains that "All the provisions now in the Fort will be far from sufficient to serve the number of hands I have to provide for... if we dont [sic] receive much provisions from the Indians we shall be in want here even should the ship [from Europe] arrive in August." ${ }^{147}$ A few days later Thomas wrote to Atkinson at Eastmain, "we shall be obliged to go on short allowance if I dont [sic] receive much provisions from the Indians, and what dependence can I place on that when only last Shiptime I was obliged to

43 John Thomas to George Atkinson, Moose Fort, 4 April 1784, in E. E. Rich, ed., Moose Fort Journals 1783-85 (London: The Hudson's Bay Record Society, 1954), 183.

${ }^{44}$ George Atkinson to John Thomas, Eastmain, 15 April 1784, in E. E. Rich, ed., Moose Fort Journals 1783-85 (London: The Hudson's Bay Record Society, 1954), 187. The challenges of attracting Indigenous providers during the goose hunt season also caused major food supply problems at the York Factory post in the early 1790 s, as the Cree people of the area preferred to hunt caribou and other game and could not easily be enticed to hunt geese for the Company: see Victor Lytwyn, "The Hudson Bay Lowland Cree in the Fur Trade to 1821: A Study in Historical Geography," Ph.D diss. (University of Manitoba, 1992), 411-412.

45 John Thomas to Edward Jarvis, Moose Fort, 4 July 1784, in E. E. Rich, ed., Moose Fort Journals 1783-85 (London: The Hudson's Bay Record Society, 1954), 205.

${ }^{46}$ John Thomas Instructions to Phillip Turnor, Moose Fort, 18 September 1784, in E. E. Rich, ed., Moose Fort Journals 1783-85 (London: The Hudson's Bay Record Society, 1954), 236.

47 John Thomas to Edward Jarvis, Moose, 1 July 1785, in E. E. Rich, ed., Moose Fort Journals 1783-85 (London: The Hudson's Bay Record Society, 1954), 308. 
broach the European provisions to serve the men," before going on to lament having to use European provisions that are supposed to purely "be kept for inland Service. ${ }^{1 / 4}$ There is a sense of desperation in this letter, as Thomas knows that if he broaches the European provisions to supply Moose Fort, then the Fort's inland dependencies will be forced to do without.

As the above examples indicate, the Fort's continual dependence on Indigenous providers to supply itself became abundantly clear when providers offered less food than usual, or opted not to stay near the Fort in the first place. But even with the crucial provisioning of the post by Indigenous providers, Moose Fort's obligations to provision both itself and its inland dependencies often left its supplies stretched thin. By the time John Thomas had become Chief at Moose in 1782, provisioning the inland posts had become a routine responsibility of the Fort, and from then on, it soon became clear that the Fort had overextended itself. ${ }^{49}$ In a letter to Edward Jarvis of Albany Fort in August 1785, John Thomas vented about the pressures and frustrations facing him as Chief of Moose Fort, deploring that "Moose... can barely supply itself, and indeed a fortunate hunt or assistance from Eastmain only enables us to supply our inland dependences the more amply. ${ }^{\prime \prime}$ It becomes clear that in this time of overextension, Moose Fort was more dependent than ever on Indigenous hunters, trappers, and fishers to secure the means to its continued survival.

As discussed previously, many historians studying the fur trade have argued or assumed that Indigenous people became utterly dependent on the fur trading Forts for their survival, at both Moose Fort and elsewhere. Beyond the examples already discussed, it also bears mentioning that some of these historians have focused particularly on the adoption of European guns by Indigenous hunters, presenting it as evidence that Indigenous people swiftly became dependent on a continual supply of ammunition from European traders in order to procure the means of their subsistence. E.E. Rich was one major proponent of this model of dependency. He argued that within a decade of becoming acquainted with European goods, Indigenous peoples "became utterly dependent on regular European supplies. The bow and arrow went out of use, and the Indian starved if he did not

48 John Thomas to George Atkinson, Fort Moose, 7 July 1785, in E. E. Rich, ed., Moose Fort Journals 1783-85 (London: The Hudson's Bay Record Society, 1954), 308-309.

49 Judd, "Mixed Bloods at Moose Factory," 68, 71.

50 John Thomas to Edward Jarvis, Moose Fort, 9 August 1785, in E. E. Rich, ed., Moose Fort Journals 1783-85 (London: The Hudson's Bay Record Society, 1954), 317. own a serviceable gun, powder and shot." ${ }^{51}$ Charles A. Bishop has similarly argued that guns and ammunition became necessities for the Western James Bay Cree within a few decades after the establishment of fur trading relations, $^{52}$ and Harold Hickerson cited an increasing reliance on guns as evidence that Indigenous people in North America had "lost their economic freedom." ${ }^{53}$ These arguments of dependence are largely predicated on the assumption that guns swiftly, completely, and uniformly replaced the existing Indigenous technology of the bow and arrow. However, as historians Daniel Francis and Toby Morantz have discussed, there are significant grounds to question this assumption, as post records at the Eastmain trading post in the James Bay region record bows and arrows being used alongside guns during hunts as late as the 1760 s. At the very least, this evidence suggests that the extent of Indigenous dependency on guns in the James Bay region was not by any means uniform, swiftly established or total. ${ }^{54}$

Moreover, the evidence concerning the relations of food exchange at Moose Fort suggests a more nuanced view of Indigenous dependency than previous, one-sided models have presented. One need only look at the 149 recorded instances of the Fort receiving food from Indigenous providers in the period under discussion, in contrast to the mere thirteen references to the opposite, to begin to understand that Indigenous providers were not nearly as dependent on this relationship as the men of the Fort were. As Daniel Francis and Toby Morantz have similarly concluded in their study of the Eastmain trading post, if the traders had had to rely solely on their own hunting expeditions to provision the post, "they would have starved. ${ }^{155}$ Furthermore, suggestions that the Indigenous homeguard had utterly given up their independence and

51 E.E. Rich, The Fur Trade and the Northwest to 1857 (Toronto: McClelland and Stewart, 1967), 102; Francis and Morantz, 168.

52 Bishop, "The First Century," 42.

${ }^{53}$ Hickerson, "Fur Trade Colonialism and the North American Indian," 24.

${ }^{54}$ Francis and Morantz, Partners in Furs, 61-63. The incorporation of firearm technology alongside existing bow and arrow technology, rather than replacing it, has also been noted among other Indigenous peoples in North America; the loways, for instance, continued to preserve and transmit knowledge of bow and arrow technology alongside firearm technology into at least the midnineteenth century. See Saul Schwartz and William Green, "Middle Ground or Native Ground? Material Culture at lowaville," Ethnohistory 60, no. 4 (Fall 2013), 552.

${ }^{55}$ Francis and Morantz, Partners in Furs, 88-89. Their tabulation of the country food consumed at Eastmain conclusively demonstrates that most provisions at Eastmain were brought by the Indigenous homeguard. Francis and Morantz also point to complaints by the post's Chief, George Atkinson, that his men simply did not know how to hunt properly. 
economic freedom ${ }^{56}$ are revealed to be faulty. The homeguard of Moose Fort, by choosing to stay at the Fort, had entered into a reciprocal relationship of food exchange by which they relied on sporadic supplying by the Fort to help cope with the disadvantages of living near the coast; ${ }^{57}$ thus, they were arguably dependent on the Fort to some extent as long as they stayed there. However, it is important to note that as the foremost providers of food to the Fort, the majority ultimately retained control over their means of subsistence and their economic choices. If they became dissatisfied with the arrangement, homeguard Indigenous hunters generally had the option to opt out of their relations to the Fort and move inland, where game (especially big game) was more plentiful, to become fulltime subsistence hunters again. Alternatively, they could go to the HBC's rivals. ${ }^{58}$ As discussed, times when most of the Indigenous providers of Moose Fort did choose to stay away from the area highlight not only a lack of abject dependence on the Fort, but also the Fort's profound dependence on them. This evidence could not be further from the views of the fur trade historians touting the traditionally one-sided models of Indigenous dependency theory. Their evaluations do not adequately acknowledge the reciprocity of these relations; moreover, they fail to take into account the full range of options available to most of the homeguard, treating homeguard members' decisions to stay near the post as final, irreversible and constituting a total forfeiture of independence. ${ }^{59}$

In reality, the journals and correspondence books of Moose Fort from 1783-85 show these relations to be more fluid. It becomes clear that the homeguard were not as irreversibly tied to the post as has traditionally been assumed. Indeed, the men of the Fort were more dependent on them for their own subsistence, as the

${ }^{56}$ See for example Hickerson, "Fur Trade Colonialism and the North American Indian," 24, and Judd, "Sakie, Esquawenoe, and the Foundation of a Dual-Native Tradition at Moose Factory," 93-94.

${ }^{57}$ Bishop, "The First Century," 46; Francis and Morantz, Partners in Furs, 94.

${ }^{58}$ Morantz, The White Man's Gonna Getcha, 18, 24; Francis and Morantz, Partners in Furs, 81-83, 93; Lytwyn, "The Hudson Bay Lowland Cree in the Fur Trade to 1821," 409. As Lytwyn shows, when the traders at Albany Fort failed to honour their reciprocal obligations to provide food at one point in 1784, Cree hunters threatened to stop provisioning the Fort, and this threat was not taken lightly. Additionally, Francis and Morantz detail how groups of the Moose Fort homeguard frequently visited the homeguard of Eastmain (at a distance of more than $150 \mathrm{~km}$ ) in the summers throughout the late eighteenth century, indicating significant mobility. The more elderly or sick members of the homeguard, though, many of whom were engaged in trapping near the post (as we have seen), would have most likely lacked this extent of spatial mobility.

${ }^{59}$ Morantz, The White Man's Gonna Getcha, 24-25. homeguard continually provided much-needed food to the Fort in copious quantities. In exchange, the homeguard demanded not only the initial payment of European goods, but also the provision of food for themselves and their families (possibly the very same food they had brought) in leaner times. This was not a sign of abject dependency on the Fort; rather, it was a tacitly understood agreement that they had voluntarily entered into with the Fort, which was in accordance with Cree values of reciprocity. The traders of Moose Fort agreed and generally upheld their side of the bargain, not only because they were continually dependent on the foods brought in by Indigenous providers, but also because they wanted to better promote the fur trade with Indigenous peoples in a climate of competition with the North West Company. But on the whole, much like in "Chakaapaash Encounters Whitemen," the Indigenous contributions of food to the Fort vastly outweighed the traders' provision of food to Indigenous people throughout the period in question. Moreover, the food supply pressures and crises that arose at the Fort when most homeguard Cree headed inland highlight both the Indigenous providers' lack of abject dependence on the Fort, and the true extent of the Fort's dependence on them for provisions. Thus, as Daniel Francis and Toby Morantz have suggested, perhaps interdependence is a more useful concept to think of in this context than simple dependence. It conveys much more accurately and holistically the reciprocal nature of the relations that developed in this period between fur traders and homeguard Indigenous people, and allows for a fuller understanding of how and why each party forged these relationships. $^{60}$ The case of Moose Fort calls for more nuanced, and less one-sided, models of dependency in the fur trade; above all, it emphasizes that any historical discussions of Indigenous dependency on fur trading forts remain incomplete without consideration of the simultaneous dependency of the traders on Indigenous providers.

\footnotetext{
${ }^{60}$ Francis and Morantz, Partners in Furs, 168, 94.
} 


\section{Bibliography}

Bibeau, Donald. "Fur Trade Literature from a Tribal Point of View: A Critique." In Rethinking the Fur Trade: Cultures of Exchange in an Atlantic World, edited by Susan Sleeper-Smith, 65-79. Lincoln: University of Nebraska Press, 2009.

Bishop, Charles A. "The First Century: Adaptive Changes Among the Western James Bay Cree between the Early Seventeenth and Early Eighteenth Centuries." In The Subarctic Fur Trade: Native Social and Economic Adaptations, edited by Shepard Krech, 21-53. Vancouver: University of British Columbia Press, 1984.

Careless, J.M.S. Canada: A Story of Challenge. Toronto: Macmillan Company of Canada Ltd., 1970.

Carlson, Hans M. Home is the Hunter: The James Bay Cree and Their Land. Vancouver: UBC Press, 2008.

Francis, Daniel, and Toby Morantz. Partners in Furs: $A$ History of the Fur Trade in Eastern James Bay, 16001870. Montreal: McGill-Queen's University Press, 1983.

Glazebrook, G.P. de T. Introduction to Moose Fort Journals 1783-85, edited by E. E. Rich, xiii-xxx. London: The Hudson's Bay Record Society, 1954.

Hickerson, Harold. "Fur Trade Colonialism and the North American Indian." The Journal of Ethnic Studies 1, no. 2 (Summer 1973): 15-44.

Innis, Harold. The Fur Trade in Canada: An Introduction to Canadian Economic History. Toronto: Toronto University Press, 1970.

Judd, Carol M. "Mixed Bloods of Moose Factory, 1730 -1981: A Socio-Economic Study." American Indian Culture and Research Journal 6, no. 2 (1982): 65-88.

---. "Sakie, Esquawenoe, and the Foundation of a DualNative Tradition at Moose Factory." In The Subarctic Fur Trade: Native Social and Economic Adaptations, edited by Shepard Krech, 81-97. Vancouver: University of British Columbia Press, 1984.
Lytwyn, Victor. "The Hudson Bay Lowland Cree in the Fur Trade to 1821: A Study in Historical Geography." Ph.D diss., University of Manitoba, 1992.

Morantz, Toby. "Old Texts, Old Questions: Another Look at the Issue of Continuity and the Early Fur Trade Period." The Canadian Historical Review 73, no. 2 (June 1992): 166-193.

---. The White Man's Gonna Getcha: The Colonial Challenge to the Crees in Quebec. Montreal: McGill-Queen's University Press, 2002.

Rich, E.E. The Fur Trade and the Northwest to 1857. Toronto: McClelland and Stewart, 1967.

---. The History of the Hudson's Bay Company, 1670-1870, vol. 1. London: Hudson's Bay Record Society, 1958.

---, ed. Moose Fort Journals 1783-85. London: The Hudson's Bay Record Society, 1954.

Schwartz, Saul, and Green, William. "Middle Ground or Native Ground? Material Culture at lowaville." Ethnohistory 6o, no. 4 (Fall 2013): 537-565.

Scott, Colin. "Encountering the Whiteman in James Bay Cree Narrative History and Mythology." Aboriginal History 19, no.1 (1995): 21-40.

Van Hoek, Stephen P. "Untangling the Roots of Dependency: Choctaw Economics, 1700-1860." American Indian Quarterly 23, No. 3/4 (SummerAutumn, 1999): 113-128.

White, Richard. The Roots of Dependency: Subsistence, Environment and Social Change Among the Choctaws, Pawnees, and Navajos. Lincoln: University of Nebraska Press, 1988. 
Food Exchange at Moose Fort, 1783-85 (Ruten)

University of Saskatchewan Undegraduate Research Journal 